\title{
Development of the Urban Periphery and Issues Related to Urban Landscape Due to Gated Communities
}

\author{
Sevin Aksoylu \\ Anadolu University, Eskişehir, Turkey
}

\begin{abstract}
Due to the industrialisation and rapid urbanisation after 1950's, housing demand has increased together with an insufficient housing production to meet the need in Turkey. As a consequence of the large deficit between the annual housing demand and supply, squatter housing construction was the major means for shelter of low income families who can not have their place in the housing market as buyers. Squatter houses are located either on the peripheries of the cities or mostly outside of the urban boundaries on public land or illegally subdivided land by creating many physical, social and environmental problems. After 1990's, depending on the globalisation wind and neo-liberal policies that enriched the new elites who have new life styles, the housing capital focused on these group. After 1999 earthquake in Turkey, the fear of possible earthquake has also changed the housing preference as from the high-rise apartment buildings to the lower detached houses. As a consequence of this supply-demand chain, the private housing investment was directed to the gated communities which are isolated settlements with restricted access, so that public spaces are privatised or their use is prohibited or controlled on the edge of the metropoliten cities. These settlements also have physical and social problems. This paper will analyze the change of urban periphery, location and relation with the natural thresholds and the main transportation system of these settlements of Turkey in the light of literature review and some development plans and interview with real estate developers and users.
\end{abstract}

Keywords: urban landscape, urban periphery, urban sprawl

\section{Introduction}

The 1950's started with a multi-party system and a liberal economic development model where priority was given to rapid industrialisation and urbanisation in Turkey (Şenyapıl1, 2004). High amount of rural-urban migration have been observed due to the agricultural mechanization and industrialization during this period. Depending on the rapid urbanization, overall housing need has been increased together with an insufficient housing production to meet the need. As a consequence of the large deficit between the annual housing demand and supply, the migrants who were mostly young population, built their squatters either on the peripheries of the cities or mostly outside of the urban boundaries on public land or illegally subdivided land by creating many physical, social, and environmental problems (Aksoylu, 1994). Starting in the late 1960s, the solution tried to be brought by the Squatter Act, to improve squatter houses which were considered to be in relatively good condition by constructing infrastructure and services to these settlements. As a result, many squatter settlements turned into established low-density residential neighbourhoods with

Sevin Aksoylu, Dean of Faculty of Architecture and Design, Anadolu University. 
infrastructure and some services (Erman, 2001). Since the 1980s, the Turkish economy has been dominated by neo-liberal policies such as privatization, decentralisation and a more deregulated open economy (Guzey \& Özcan, 2010).

Transformation in the economic system has resulted in the transformation of some of the squatter housing from the use value to exchange value when the land value increased parallel to the urban development (Cinar, Cizmeci, \& Koksal, 2006). A group of squatter laws (2805, 2981/3290) were enacted in Turkey after 1980's. These laws determined the ways to legalize the all anauthorized buildings, not only squatters but also the other types, even in the planned areas. The laws also required the elaboration of Reconstruction Upgrading Plans. The real titles would be given after the preparation of these plans. Existing houses would be conserved as much as possible, but the densit could be increased 2-3 times by increasing the existing storeys of houses from single storey to 3-4 in the upgrading plans (Aksoylu, 1994). Today many of the houses built before 1985, the year when the last Squatter Amnesty Law was passed, have title deeds, however those built afterwards lack them. Those who have title deeds replaced their squatter houses by multi-story apartment buildings. Thus, most of these squatter houses were demolished and new condominiums were built instead on the peripheries. The opening of the economy to direct foreign investments in the country has led to big changes in the spatial configuration specifically in Istanbul. The city center was dislocated and the land rapidly opened for new demands like office blocks, department stores, and five-star hotels, construction companies that prospered ventured to major housing projects in the urban periphery. Therefore, high-income groups left the city center due to the low quality of life in inner-city areas (Çekiç \& Gezici, 2005). They show a tendency to live in urban peripheries by bringing a new phenomenon as gated communities where higher building standards and high-quality housing environmental infrastructures, special amenities, large variety of leisure activities were provided. Growth dynamics of these settlement has resulted in not only uncontrolled sprawl in the city, but also a fragmentary structure in which resources are distributed unevenly (Berköz \& Tepe, 2013). Fragmentary structure has come to threaten the natural resources and became a new issue on the periphery of the metropolitan cities while squatter settlements are still a concern. Hence, in this paper, gated communities, in terms of the development of the metropolitan periphery and their effects on natural thresholds constitute the focal points. One of the main hypotheses has been raised that gated communities have an effective role on changes of the land use pattern in the periphery and the environment. In order to test these hypotheses, the analysis has focused on the transformation of the periphery after 1980's. From this perspective, "What are the negative impacts of so-called gated communities on the development of the metropolitan periphery?" has been established as the main question of this paper.

\section{Urban Sprawl and Expansion of the Built-UP Areas Towards the Peripheries}

\section{Definition of Urban Sprawl}

Rapid and unbalanced urban development with the transportation network particularly in the suburban areas have resulted in urban sprawl phenomenon and it has contributed serious problems since 20th century. Sprawl occurs in almost every county of the United States, Western and Eastern European, Latin American, and Asian countries in response to growing dependence on the automobile as the preferred method of intra- and inter- metropolitan travel (Burchell et al., 1998). A survey of the literature yields no agreement in terms of defining and measuring urban sprawl (Galster et al., 2001). Some of the definitions can be summarized as follows. Urban sprawl is “... uncontrolled development of land situated on the outskirts of America's major 
cities" (Callies, Freilich, \& Roberts, 1999). Nelson et al. (1997) describes urban sprawl as “ ...unplanned, uncontrolled and uncoordinated single use development that does not provide for an active and functional mix of uses and/or is not functionally related to surrounding land uses and which variously appears as low density, ribbon or strip scattered, leapfrog or isolated development" (Nelson et al., 1997). Urban sprawl refers to a specific form of urban development characterized by low-density, leapfrog, commercial strip development and discontinuity in these definitions (see Figure 1) (Galster et al., 2001; Ewing, 1997; Downs, 1999). Urban sprawl is an inevitable consequence of the spontaneous development of cities. Sprawl occurs when the rate of land use conversion and consumption for urban uses exceeds the rate of population growth for a given area over a specified period.

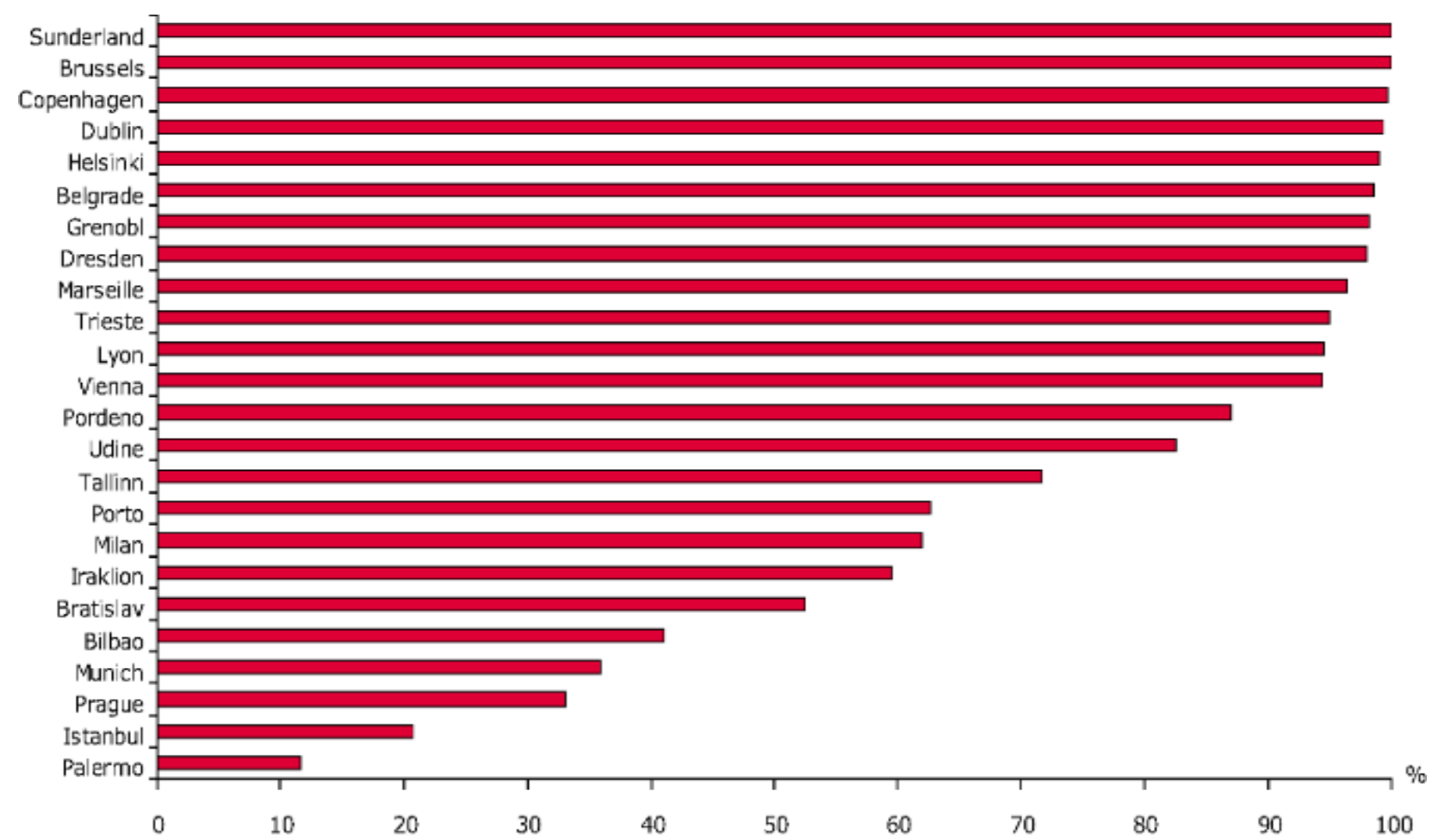

Figure 1. Low density residential areas as a proportion of all residential areas built after the mid 1950's selected European cities (EEA, 2006).

Historical trends, since the mid-1950s, show that European cities have expanded on average by $78 \%$, whereas the population has grown by only 33\%. In particular, over the past 20 years the extent of built-up areas in many Western and Eastern European countries has increased by $20 \%$ while the population has increased by only 6\% (European Environment Agency, 2002, 2006). In the United States, cities have experienced the same trend, with peri-urbanization claiming nearly $60,000 \mathrm{~km}^{2}\left(23,166 \mathrm{mil}^{2}\right)$ of land between the 1980s and 1990s.

\section{Negative Impacts of Urban Sprawl}

Urban sprawl as the primary form of urban development has come under increased criticism not only because of its negative environmental impacts, but also social and economic effects (Ewing, 1997; Burton, 2000; Jenks et al., 1996; Breheny, 1992; Elkin et al., 1991; Newman \& Kenworthy, 1989; Hasse, 2003; Shen \& Zhang, 2007). It is known that with respect to high-density urban areas with high-rise buildings, dispersed and 
widespread low-density urban development occupy more land which has significant negative effects on land and natural resources. The dispersion leads to the rapid transformation of the forests, drinking water reservoirs, and agricultural areas in the peripheries of urban areas into the existing settlements (Gillham, 2002). In the major cities of developing countries, urban sprawl also threatens the natural resources through large-scale land consumption (Burchell et al. 1998). Urban sprawl is synonymous with unplanned incremental urban development, characterized by a low density housing, non-contiguous, automobile dependent, residential and non-residential development on the urban fringe that consumes relatively large amount agricultural land and natural resource areas (Burchell et al., 1998; Ewing, 1997; Gillham, 2002). It was fuelled by the rapid growth of private car ownership and the preference for detached houses with gardens.

Development is patchy, scattered and strung out, with a tendency for discontinuity gas and emissions that cause climate change and elevated air and noise pollution levels which often exceed the agreed human safety limits. Thus, urban sprawl produces many adverse impacts that have direct effects on the quality of life for people living in cities. Under these circumstances, drinking water resources, wild life, the quality of the existing settlements, as well as the quality of all natural and physical settlements are affected (see Figure 2) (Matlack, 1993; Zuidema, Sayer, \& Dijkman, 1996; Mc Donnell et al., 1997; McKinney, 2002). In the 1990s, American moved from metropolitan centers to rural areas and only one-third of American living in metropolitan areas remained in city centers. Gated communities became increasingly popular in Turkey especially in Istanbul after 1980's as well as the American and European cities.

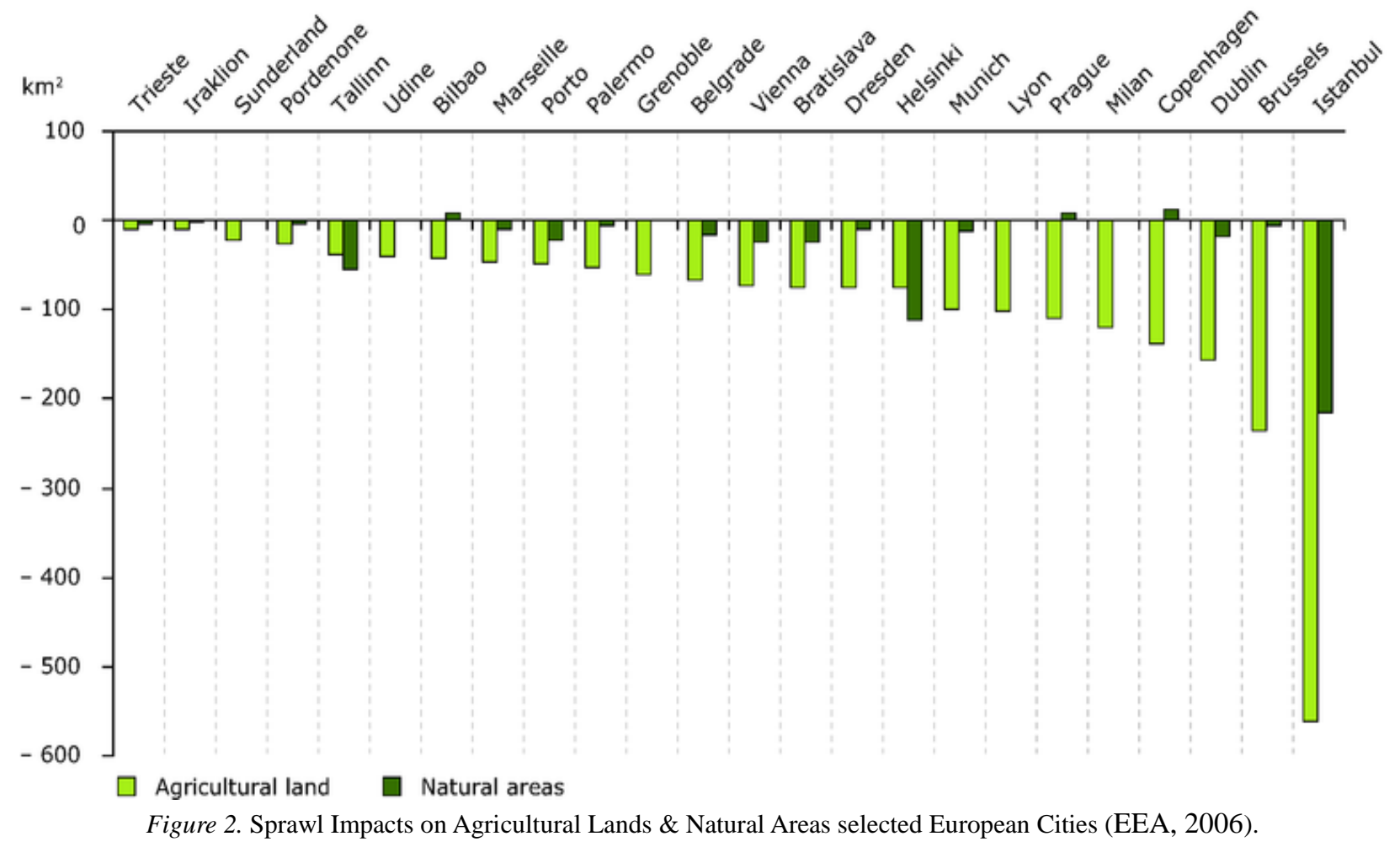

Newly built single-family gated housing areas developed at the urban peripheries have become the subject of much criticism in planning circles because of the environmental impacts on natural resource qualities (Low, 2000; Keleş, 1993; Bölen, 2004). 


\section{Urban Sprawl and the New Housing Trends on the Periphery in Turkey}

\section{Development of Periphery in Turkey After 1950's}

The nature of the urban spatial structure of metropolitan cities in Turkey started to change after the 1950s (Keleş, 1993; Bölen, 2004). The 1950's started with a multi-party system and a liberal economic evelopment model where priority was given to rapid industrialization and urbanization. The rapid urbanization and migration from rural to urban areas, which was accelerated by industrialization, played an important role in the development of urban areas. The financial cost of informal housing was lower than formal housing and was preferred by migrants. As a result of this, metropolitan cities of Turkey has faced huge growth of informal residential areas on the periphery starting from the 1950s when the shortage of affordable housing created informal housing primarily because of rural to urban migration (see Figure 3). These settlements, which were located either on the peripheries of the cities or mostly outside of the urban boundaries on public land or illegally subdivided land were low density caused by accelerated the expansion of metropoliten cities (Bölen, 2004; Aksoylu, 1997) and accelerated urban expansion and sprawl (see Figure 4).

As a consequence, illegal/informal residential areas have started to invade the water basins, forests and high-quality agricultural land (Bölen et al., 2007). An important break for the squatter population came with the 1960's as developing countries adopted planned development models. The previous liberalization model had failed to achieve equal distribution of benefits of development and had resulted in serious unemployment problems due to slow industrialization (Şenyapıl1, 2004). During the planned period which starts in 1963 various targets have been defined and with the goals and provisions some proposals have been tried to develop for solving the problem (DPT, 1963). At the beginning of this period, Ministry of Construction and Housing have accepted the problem as the municipalities' problem and it hasn't wanted to assume responsibility. But at the end of the First Planning Period (1963-1967), agreement of opinion was obtained that their problem must be solved not only by municipalities but also by governments. In 1966, widely known "Squatter Law" Act No: 775 which was the first legislation specifically concerned with squatters (Tokman, 1984) was enacted and for the first time, the dual housing stock was accepted, the planned, modern section and the squatter areas.

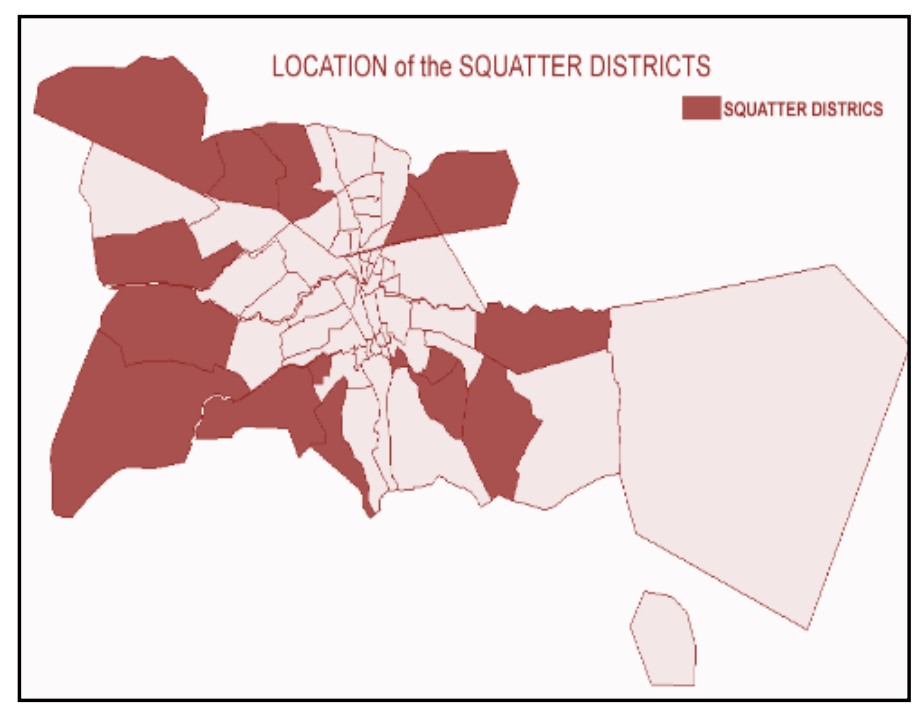

Figure 3. Location of Squatter Settlements of Eskişehir-Turkey. 


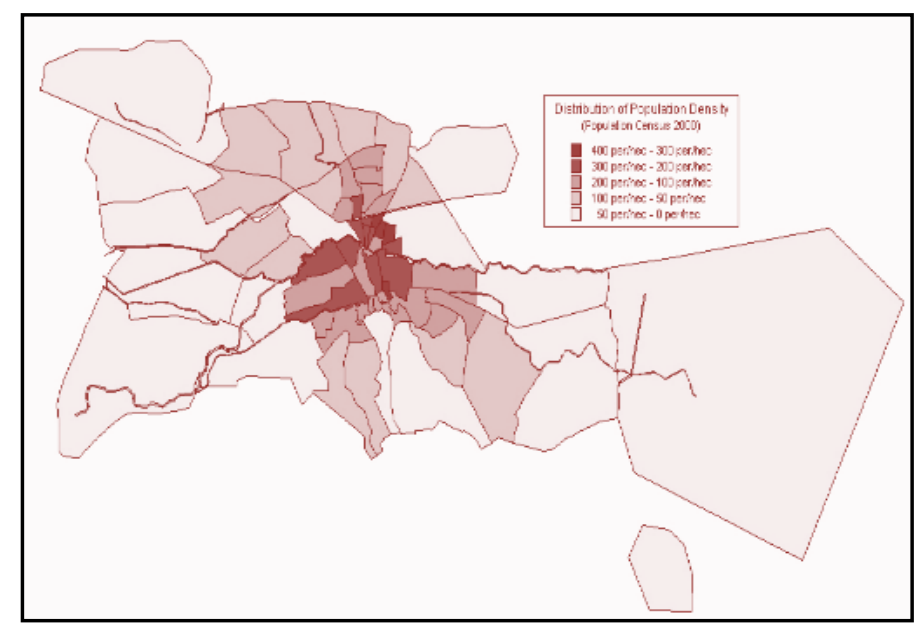

Figure 4. Distribution of Population Density of Informal Houses in Eskişehir (Aksoylu, 1997).

\section{Gated Communities and Development of Urban Periphery After 1980's}

During the second half of the 1980s with the neo-liberal policies going hand in hand with the developments in the world, Turkey entered to a new era. In this era, the Turkish economy has been dominated by neo-liberal policies such as privatization, decentralization and a more deregulated, open economy. The process has stimulated the importance of Istanbul with its location is being open to international connections and as the center of regional commerce and communication. The opening of the economy to direct foreign investments in the country has led to change in the urban fabric of Istanbul and some other metropolitan cities with the appearance of shopping centers, international hotels, international banks and trade companies, rezidences and gated communities. Small and medium-size entrepreneurs were discarded, which had direct reflections on the construction sector in terms of high capital and technology (Guzey \& Özcan, 2010; Erkip, 2000). The infrastructure projects such as the construction of the highways and the 2nd Bosphorus Bridge were carried out which led to the development of the northern parts of Istanbul and the obliteration of the natural resources, which later introduced the deforestation threat to the city (see Figure 5) (Çekiç \& Gezici, 2005; Berköz \& Tepe, 2013). The peripheries of Istanbul, hosting a population of 5,842,958 in 1985, mushroomed with houses and squatter settlements, increasing the spatial growth (Municipality of Istanbul Metropolitan Area, 1995). The Mass Housing Law was enacted in 1984 accelerated the construction of big-size multi storey housing projects, encouraging new implementation by cooperatives as well as private sector housing entrepreneurs.

The multi-faceted transformation after the 1980's made a great impact on squatter housing as well. The squatter housing stock commercialized through a set of Amnesty Laws. As a most important differentiation from the previous law, existing houses would be conserved as much as possible, but the density could be increased 2-3 times by increasing the existing storeys of houses from single storey to 3-4 in the upgrading plans (Aksoylu, 1994). The squatters have been transformed as being increasingly built by contractors instead of the owners themselves. More than $75 \%$ of the land is bought from the previous owners and again $75 \%$ of dwellings are either bought $(25 \%)$ or contracted (50\%) in the squatter settlements in Istanbul (SPO, 1991; Erder, 1996). Thus, both formal and informal housing investments turned out to be the parts of an "immoral (Kasanko et al., 2006) economy of housing" which are determined by "reciprocity relations" between state and various power groups (Buğra, 1998). The policy that enabled the intensification of informal residential areas made a significant impact on urban form, however, large-scale mass housing investments in the periphery caused the 
continuance of sprawl (see Figure 6). Beginning from 1990s, the gated community developments occurred in the peripheries of the big cities especially in Istanbul. Heterogeneous housing areas inside the city started losing popularity among the high income groups who instead showed a tendency towards isolated and homogenous areas far from the city center of metropolitan cities. 1999 earthquake in Istanbul has also enhanced this phenomenon.

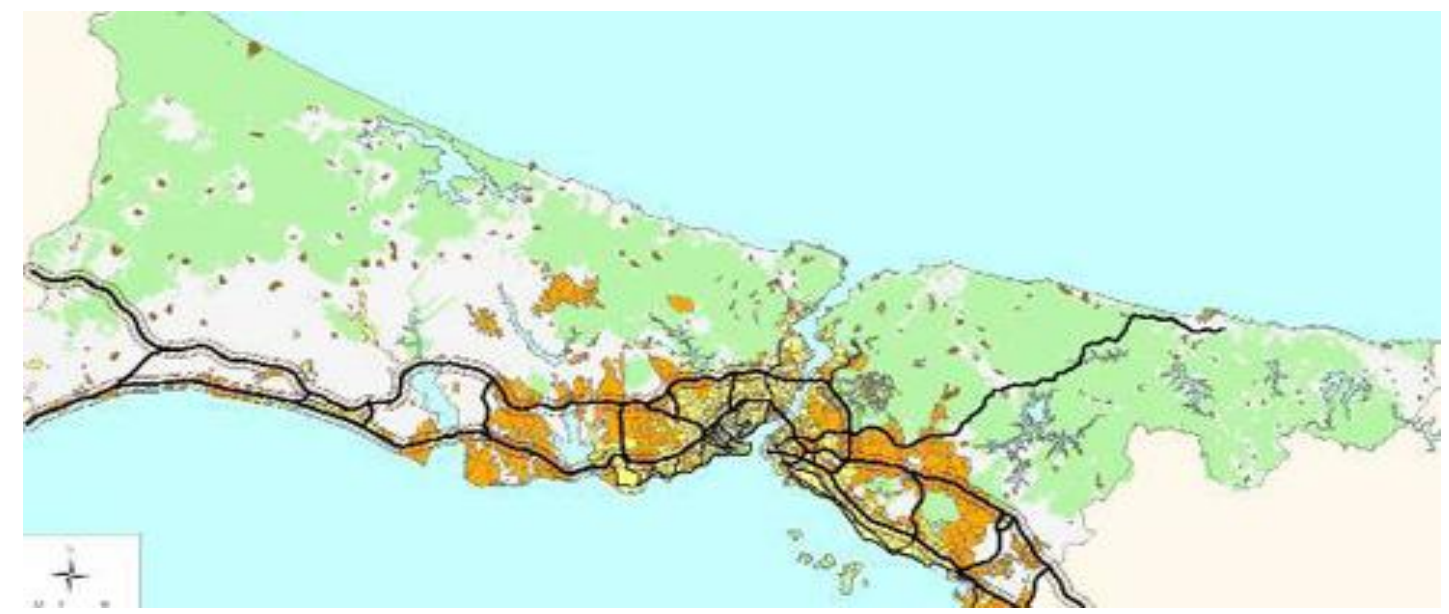

Figure 5. Effects of Highways and Bosphorus Bridges to the Land Use Change of Istanbul (MIMA, 2007).

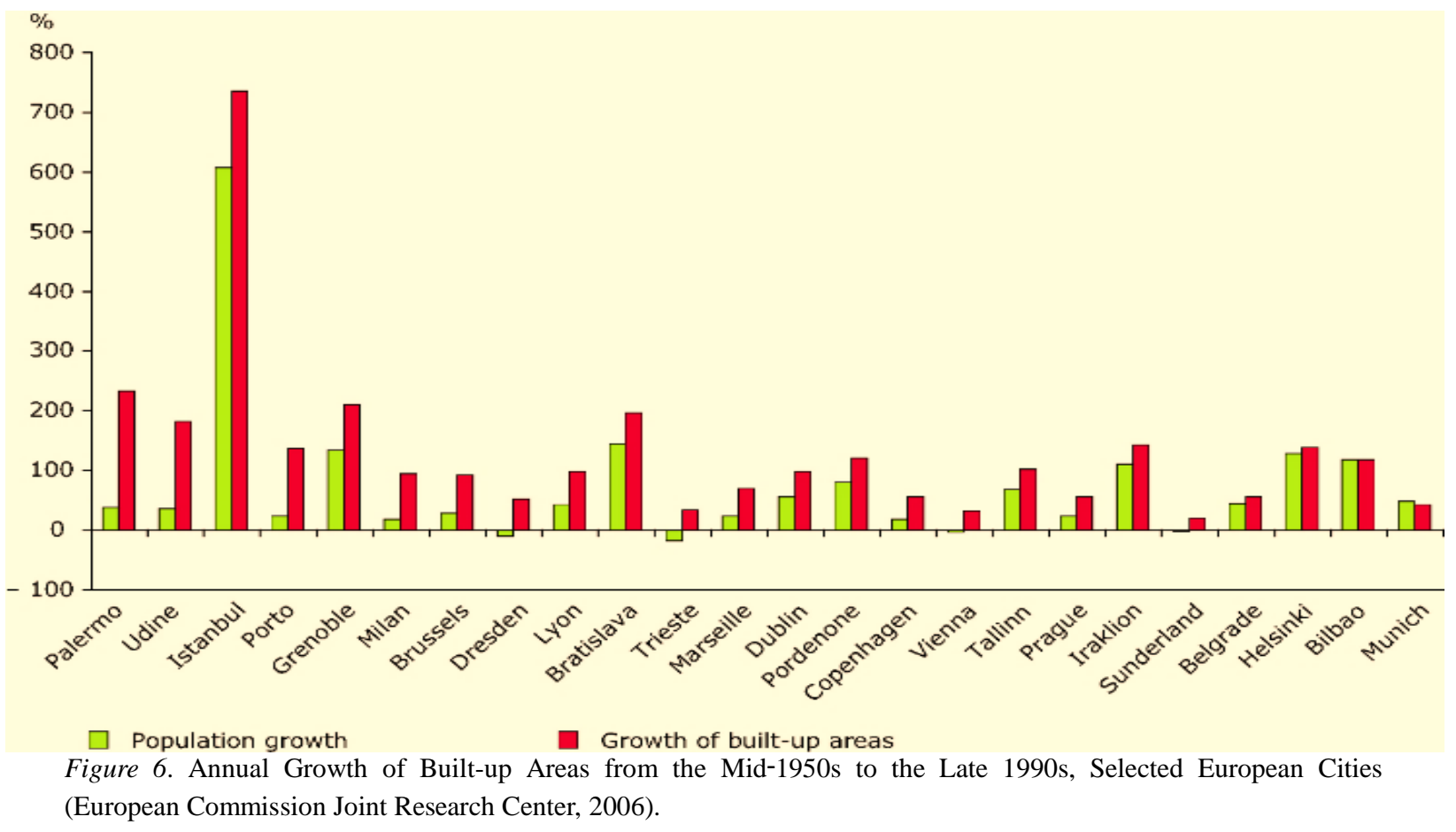

This tendency has resulted in the rapid growth of mass housing areas in the urban peripheries, which include a life style enabling the expectations of living with families at the same cultural and income level and which consist of less dense single-family housings (Berköz, 2008). According to users and real estate developer of Yenişehir Konakları which has 800 houses in Eskişehir, reasons for choosing this type of houses are; security, different house alternatives, to have social facilities, to be close to nature, to live with their friends and 
same level families ${ }^{1}$. Big pieces of land on the urban peripheries that enable the development of such homogenous housing areas and low prices of land are the reasons for the desirability of these areas in the bosom of nature, which meet the demands of high-income groups. Spatial changes from 1987 to 2001 based on the satellite views of Istanbul's European side, urbanized areas covering 11,800 ha. in 1987 increased to 26,500 ha. in 2001. It has been observed that the urbanized areas of the European side of Istanbul conveyed an increase rate of $116 \%$ in 14 years, however, the population increased by only $83.3 \%$ in the period of 1985-2000, which demonstrates that growth of built-up areas exceeded population growth on the European side of Istanbul (Kaya \& Curran, 2006). When the density change in Istanbul between 1990 and 2000 is examined, it is seen that there is a decrease in central districts with a rate of $9.18 \%$, but an increase in peripheral areas with a rate of $106.47 \%$, which results in a density twice as much as the density change of Istanbul (50.63\%) (State Institute of Statistics, 2000).

\section{Changing Fringe and Issues Related to Gated Communities in Turkey}

Gated communities are a part of the trend of suburbanization that is based on the creation of self-contained, separate communities with carefully constructed identities as well as the typical patterns of the rapid spread of proprietary urban communities of the 21 st century (Webster, Glasze, \& Frantz, 2002). The contemporary gated communities are usually analysed within a neoliberal urban context which symbolise an upper class wish for status, community life, belonging, and security, becoming more popular since the late 1970s and early 1980s. It is also emphasised that improvements in the system of suburban motorways were a very important factor in this evolution. As often happens when economic growth is high, the effects of strong speculation were added to these factors, attracting available capital into real-estate investments, and gated developments multiplied on the periphery. In the 1990s, the boom of gated communities generated so much optimism, profits and speculation that a new type of gated settlement was introduced, on a larger scale. These are huge master-planned communities that include restricted access various central and semi-public spaces and amenities such as shopping centres, swimming pools, private bars, children's play areas and a full accompaniment of care-taking staff and security forces (Blakely \& Snyder, 1997; Hook \& Vrdoljak, 2002; Low, 2003; MacLeod, 2003; McMahon, 2003; Musterd, Priemus, \& Van Kepmen, 1999). It is argued that the most important reason to prefer living in the gated communities at the periphery is to be isolated from the disadvantages of the city, such as traffic, parking problems, air pollution, noise, decrease in the level of recreational areas and etc. (Ayata, 2002). Moreover, the availability of lands big enough for the development of such communities, lower land prices with respect to the city centre, and the green belts surrounding these lands are among the reasons why peripheral areas are desirable spaces to fulfil the requirements of high-income groups (Blakely \& Snyder, 1997; Low, 2003). These settlements are composed of low-rise buildings when compared to the ones in the city and town houses. In Turkey, following the 1980s when liberal policies became effective, the efforts to attract global capital played an important role in the organization of urban space. The emergence of new forms of capital accumulation in Turkey led to a new and more polarised class structure characterised by the new middle and/or upper-middle classes working in finance, insurance, and real estate sectors, and the emergence of a new urban space, reflecting this more polarised and diversified class structure (Çekiç \& Gezici, 2005; Geniş, 2007; Oncu, 1997). During this period, new residential spaces called as gated communities have been constructed, by

\footnotetext{
${ }^{1}$ Interview with users and Real Estate Developer.
} 
prominent developer companies designed by well-known architects and proximity to various amenities reducing the need of using urban public spaces and services. Istanbul has more gated communities than any other city in Turkey, due to its being the center of domestic and international investments, has become one of the cities in which gated communities most rapidly advanced. Starting from the 1980s, Istanbul's natural beauties, such as the world-known Bosphorus, and then the suburban villages covered by dense forests were started to be sold to developer companies. These areas were transformed into settlements of gated communities and Istanbul has become the center of housing investments. They are located in areas which have geographical amenities such as a seas, lakes, and forests. Construction of the Second Bosphorus Bridge and the highways at the beginning of the 1990s, increased accessibility. The areas around this route became centers of attraction due to the demand of those escaping from urban life to dwell in the urban peripheries, the convenient accessibility of these areas to the city centre, and the low prices of land (see Figure 7). Second Bosphorus Bridge and the highways at the beginning of the 1990s, increased accessibility. The areas around this route became centers of attraction due to the demand of those escaping from urban life to dwell in the urban peripheries, the convenient accessibility of these areas to the city centre, and the low prices of land. Therefore, sprawling primarily began in the areas between this route and the coastline, gradually spreading toward drinking water basins in the north where no residential function had been projected in the master plans of the Istanbul metropolitan area (Berkoz, 2010; Çekiç \& Gezici, 2005). The changing fringes of Istanbul metropolitan area with the new transportation routes has coincided with the rapid construction of gated communities, which were racing with the speed of the 1960's squatter housing areas.

This new way of housing which is quite different than mass housing projects of the 1980's in terms of number, mode of land usage, land development and financing, changed the habits of traditional neighbourhood in Istanbul. As well as these housing projects that re-formed the fringes and geographically prestigious areas of the city, the metropolitan area with its old squatter districts, new shopping malls, and empty lands has taken a kind of patchy appearance (Kurtuluş, 2002). According to Perouse and Danış (2005), there are more than 650 gated communities in Istanbul metropolitan area in 2005. This number was 150 in 2003 (Kurtuluş, 2005). These communities were equipped with special amenities such as large variety of leisure activities, higher building standards and high quality neighbourhood environmental infrastructures. Gated communities in Istanbul created several social and environmental problems. Encouraging car-ownership and use, gated communities have various consequences such as congestion and pollution at considerable levels, and a decrease in a sustainable public transport system are two examples of these consequences (Berköz, 2006). Thus, briefly they increased suburban car-based residential sprawl, commuting time, traffic volume, air pollution and they heve caused consuming reserved vacant urban lands in urban peripheries. Apart from these, environment and natural resources such as forests and arable lands were damaged. It is seen the decrease in arable land of Istanbul between 1945 and 2000 in Figure 8. Agricultural areas decreased by 23\%, and also urban sprawl on water basins rapidly increased. During the 14-year period, forest and green areas decreased by 9,134 ha (12.13\%) and the agricultural and bare soil class by 19,656 ha (24.79\%). Due to existing vacant and low-price lands in water basin areas of Istanbul, 24\% of total gated communities which were constructed between 2000 and 2010 are located in water basin areas (Kaya \& Curran, 2006; Berköz \& Tepe, 2013). Furthermore, gated communities reflect larger socio-economic issues the wish to imitate Western way of life, regarded as status symbol (Suarez, 2011). Segregation, social inequality and disintegration of society by excluding the rest of the society are some of social issues (Marcuse, 1997). 


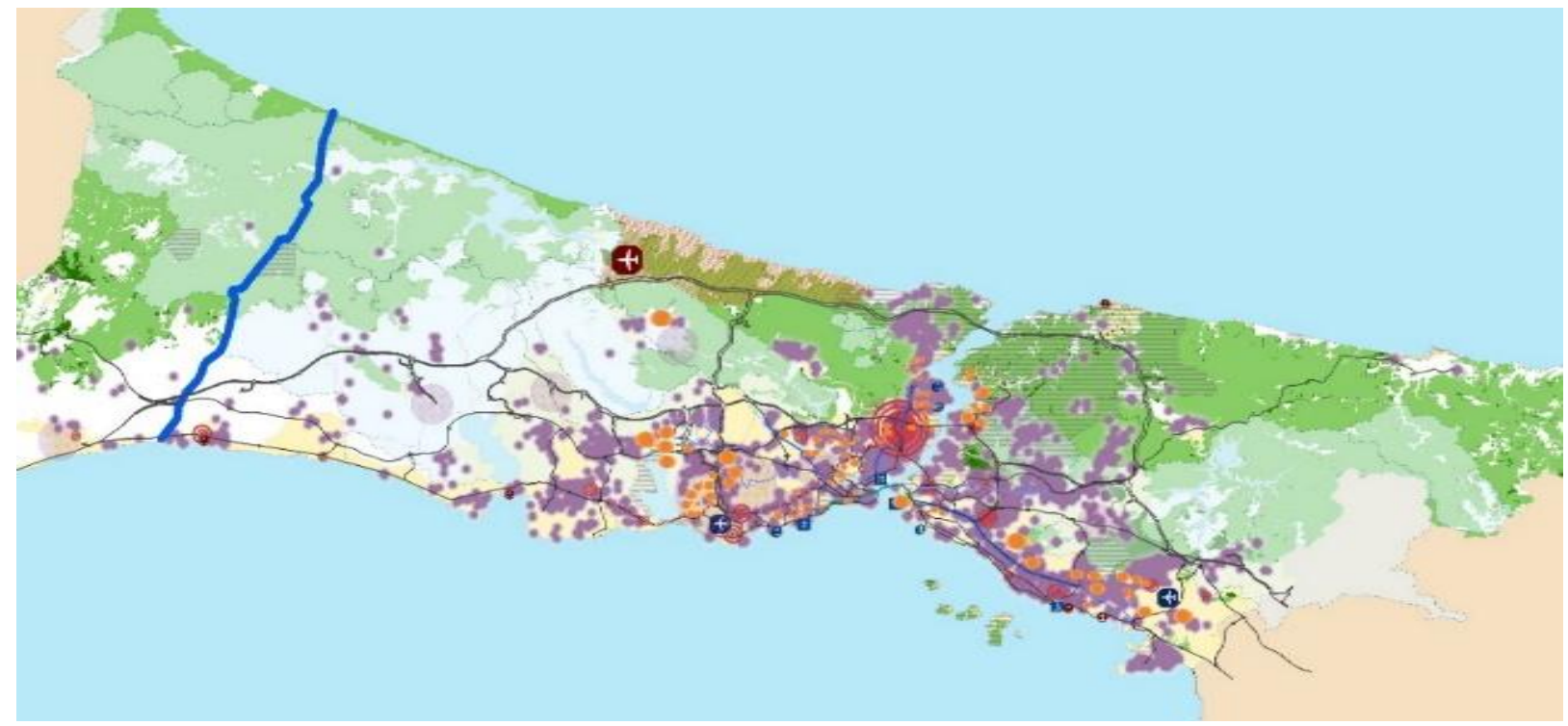

Figure 7. Distribution of Gated Communities in Istabul ${ }^{2}$.
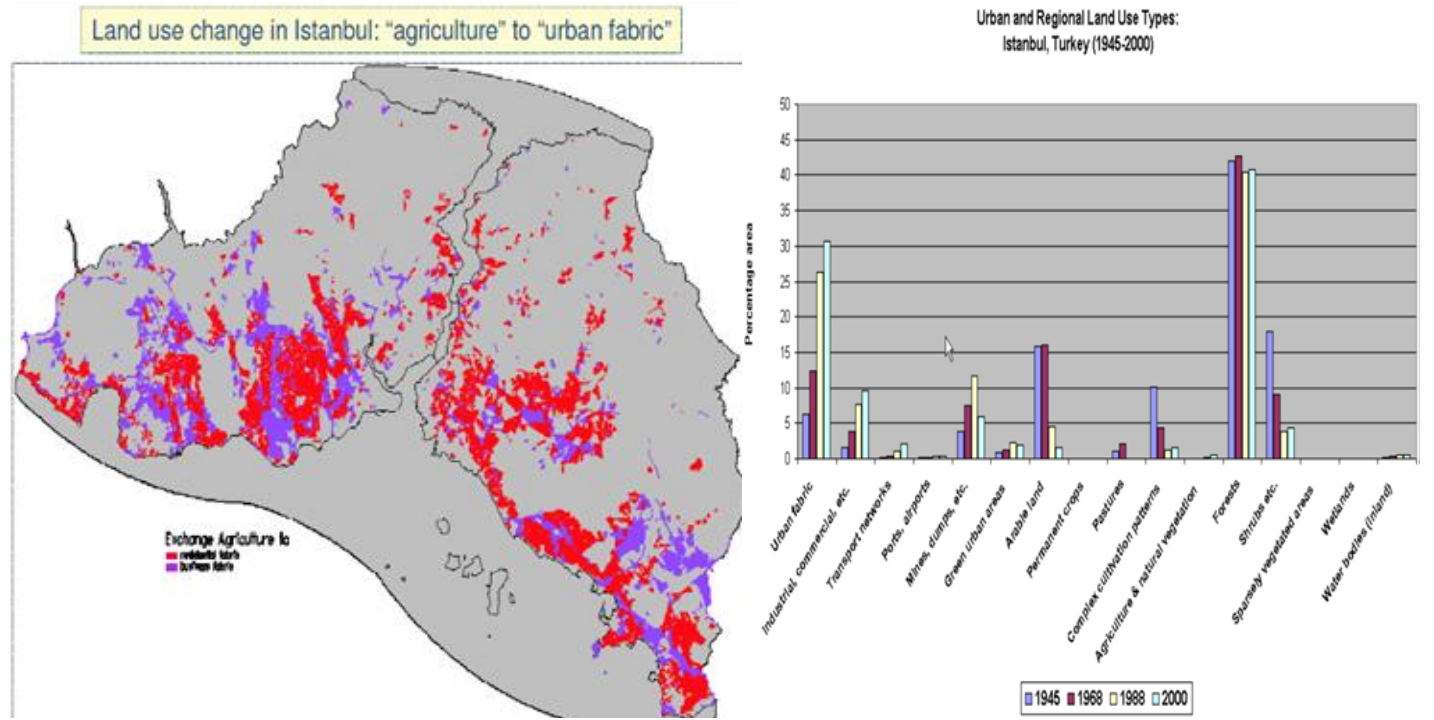

Figure 8. Land Use Change from Natural Values to Urban Fabric (European Commission Joint Research Center, 2006).

\section{Conclusion}

High income groups show a tendency to live in urban peripheries where vast lands were available for housing by bringing a new phenomenon as gated communities. Higher building standards and high-quality housing environmental infrastructures were provided in these gated communities. Growth dynamics of these settlement has resulted in not only uncontrolled sprawl in the city, but also a fragmentary structure in which resources are distributed unevenly. These residential areas have been planned as local plans independent of the master plan of the cities. In conclusion, due to low-density and widespread developments, gated communities have already occupied large amount of vacant lands of the metropolitan cities which are mainly located in the environmentally sensitive lands. Fragmentary structure has come to threaten the natural resources such as

\footnotetext{
${ }^{2}$ Retrieved from http://www.istanbulcdonusumcografyasi.wordpress.com.
} 
forests, water basins, agricultural land etc. and became a new issue on the periphery of the metropolitan cities while squatter settlements are still a concern. In order to get this development under control and be able to direct them or to limit their expansion, the following points must be taken into account. A strong connection between real estate and planning must be established to control urban sprawl and the formation of gated communities as privileged construction areas in the peripheries must be prevented. Prevention is primarily possible with development control, monitoring and implementation strategies. These are essential to promote sustainable urban development, especially under conditions of rapid urban population growth on the environmentally sensitive areas.

\section{References}

Aksoylu, S. (1994). Sustainable development in urban areas: Case Study: Eskisehir, Turkey (Unpublished Final Report for Environmental Planning and Management in IHS, Report Code: No 2190, Rotterdam, The Netherlands).

Aksoylu, S. (1997). Yasal olmayan konut alanlarinda donusum surecinin coğrafi bilgi sistemleri kullanılarak degerlendirilmesi (Evaluation of transformation process of squatter settlements by using GIS). Research Project supported by Anadolu University Center for Environmental problems and applications, Eskişehir.

Ayata, S. (2002). The new middle class and the joys of suburbia: Fragments of culture: The everyday of modern Turkey. In. D. Kandiyoti, \& A. Saktanber (Eds.). New York: I.B. Tauris \& Co Publishers.

Berköz, L. (2006). Sprawling at single family housing of İstanbul. Proceedings of XXX1V IAHS World Congress on Housing (p. 210), Napoli, Italy.

Berköz, L. (2008). İstanbul'da korunaklı tek-aile konutlarının yerseçimi özellikleri (Location characteristics of gated communities in Istanbul). ITU BAP Reseach Project (pr. No. 31981).

Berkoz, L. (2010). Single-family gated housing sprawl in Istanbul: Environmental quality and satisfaction. Germany: VDM Verlag Dr. Müller.

Berköz, L., \& Tepe, E. (2013). The impacts of the gated residential areas on the urbans Sprawl of Istanbul. SAVAP International, 4(3), 1-17.

Blakely, E. J., \& Snyder, M. G. (1997). Fortress America: Gated communities in the United States. Washington, D.C.: Brookings Institution Press.

Bölen, F. (2004). Housing policy and housing systems in Turkey. A|Z ITU Journal of Faculty of Architecture, 1(2), 14-31.

Bölen, F. et al. (2007). Quality of residential environment in a city facing unsustainable growth problems: Istanbul. Proceedings of 47th Joint Congress of the European Regional Science Association and Association de Science Régionale de Langue Française, Paris.

Breheny, M. J. (1992). Sustainable development and urban form. London: Pion.

Buğra, A. (1998). The immoral economy of housing in Turkey. International Journal of Urban and Regional Research, 22(2), 303-313.

Burchell, R. et al. (1998). The costs of sprawl-Revisited. Report No.39, Transportation Research Board, Washington, D.C.

Burton, E. (2000). The compact city: Just or just compact? A preliminary analysis. Urban Studies, 37(11), 1969-2007.

Callies, D., Freilich, R., \& Roberts, T. (1999). Cases and materials on land use (3rd ed.). St. Paul, MN: West Group.

Çekiç, T. I., \& Gezici, F. (2005). Spatial impacts of new housing trends in the periphery of the Istanbul metropolitan area. Retrieved from https://ideas.repec.org/p/wiw/ wiwrsa/ersa05p41. html \#download

Cinar, C., Cizmeci, F., \& Koksal, A. (2006). The new addressof social polarization in Istanbul: Gated communities. Proceedings of 42nd ISoCaRP Congress, Cities Between Integration and Disintegration, Opportunities and Challenge, Y1ldiz Technical University, İstanbul.

Downs, A. (1999). Some realities about sprawl and urban decline. Housing Policy Debate, 10, 955-974.

DPT, I. (1963). Bes yillik kalkinma plani 1963-1967 (Five Year Development Plan 1963-1967). State Press of the Prime Minister's, Ankara.

Elkin, T. et al. (1991). Reviving the city: Towards sustainable urban development. London: Friends of the Earth.

Erder, S. (1996). İstanbul'a bir kent kondu: Ümraniye (A city alighted to Istanbul: Ümraniye). İstanbul: İletişim Yayinlarí.

Erkip, F. (2000). Global transformations versus local dynamics in Istanbul: Planning in a fragmented metropolis. Cities, 17, 371-377. 
Erman, T. (2001). The politics of squatter (Gecekondu) studies in Turkey: The changing representations of rural migrants in the academic discourse. Urban Studies, 38(7), 983-1002.

European Commission Joint Research Center (MOLAND-JRC). (2006). Spatial analysis for monitoring and modelling urban sprawl, and analysis of vulnerability to natural hazards (i.e. floods). In Europe.

European Environment Agency (EEA). (2002). Environmental signals 2002-Benchmarking the millennium. Environmental Assessment Report, No. 9.

European Environment Agency (EEA). (2006). Urban sprawl in Europe-The ignored challenge. EEA Report No. 10.

Ewing, R. (1997). Is Los Angeles-style sprawl desirable? Journal of the American Planning Association, 63(1), 107-126.

Galster, G., Hanson, R., Wolman, H., Coleman, S., \& Freihage, J. (2001). Wrestling sprawl to the ground: Defining and measuring an elusive concept. Housing Policy Debate, 12, 681-717.

Geniş, S. (2007). Producing elite localities: The rise of gated communities in Istanbul. Urban Studies, 44(4), 771-798.

Gillham, O. (2002). The limitless city a primer on the urban sprawl debate. USA: Island Press.

Guzey, Ö., \& Özcan, Z. (2010). Gated communities in Ankara, Turkey: Park renaissance residences as a reaction to fear of crime. Gazi University Journal of Science, 23(3), 363-375.

Hasse, J. R. (2003). Land resource impact indicators of urban sprawl. Applied Geography, 23(2/3), 159-175.

Hook, D., \& Vrdoljak, M. (2002). "Gated communities, heterotopia and a rights" of privilege: A "heterotopology" of the South African security park. Geoforum, 33(2), 195-219.

Jenks, M. et al. (1996). The compact city: A sustainable urban form? London: E \& FN Spon.

Kasanko, M., Barredo, J. I., Lavalle, C., McCormick, N., Demicheli, L., Sagris, V., \& Brezger, A. (2006). Fifteen European urban areas. Landscape and Urban Planning, 77, 111-130.

Kaya, S., \& Curran, P. J. (2006). Monitoring urban growth on the European side of the Istanbul metropolitan area: A case study. International Journal of Applied Earth Observation and Geoinformation, 8, 18-25.

Keleş, R. (1993). Kentleşme politikası. Ankara: İmge Kitabevi.

Kurtuluş, H. (2002). İstanbul'da ayrıcalıklı konut alanları ve yoksulluğa kentsel kaynak transferleri çerçevesinden bir bakış: Bahçeşehir, Kemer Country, Acarkent, Beykoz Konakları (Gated communities in Istanbul and overview to the poverty in terms of urban resource transfers: Bahçeşehir, Kemer Country, Acarkent Beykoz Konakları). Yoksulluk, Kent Yoksulluğu ve Planlama (Poverty, urban poverty and planning), Publication of Chamber of City Planners, Ankara.

Kurtuluş, H. (2005). İstanbul'da kapalı yerleşmeler Beykoz konakları örneği (Gated communities in Istanbul as a case of Beykoz Mansions). In H. Kurtuluş (Ed.), İstanbul'da Kentsel Ayrışma (Urban segregation in Istanbul). Bağlam Yayınları, İstanbul.

Low, S. (2000). The edge and the center: Gated communities and the discourse of urban fear. Retrieved from http://www.gated-communities.de

Low, S. (2003). Behind the gates, life, security, and the pursuit of happiness in fortress America. New York: Routledge.

MacLeod, G. (2003). Privatizing the city? The tentative push towards edge urban developments and aged communities in the United Kingdom. International Centre for Regional Regeneration and Development Studies (ICRRDS), University of Durham, England.

Marcuse, P. (1997). The Ghetto of exclusion and the fortified enclave. American Behavioral Scientist, 41(3), 31-36.

Matlack, G. R. (1993). Sociological edge effects:spatial distribuion of human impact in suburban forest fragments. Environmental Management, 17, 829-835.

Mc Donnell, M. J. et al. (1997). Ecosystem processes along an urban-to rural gradient. Urban Ecosystems, 1, 21-36.

McKinney, M. L. (2002). Urbanization, biodiversity, and conservation. BioScience, 52, 883-890.

McMahon, E. (2003). Gateway communities. Retrieved from http://www. plannerswebcom/Wfiles/w156.html

Municipality of Istanbul Metropolitan Area (MIMA). (1995). 1/50.000 Ölçekli İstanbul Metropoliten Alan Alt Bölge Nazım Plan Raporu (Master Plan Report of subregion of Istanbul metropolitan Area with a scale of 1/50.000). Istanbul.

Municipality of Istanbul Metropolitan Area (MIMA). (2007). İstanbul metropoliten Alan Alt Bölge Nazım Plan Raporu (Master Plan Report of subregion of Istanbul metropolitan area). Istanbul.

Musterd, S., Priemus, H., \& Van Kepmen, R. (1999). Towards undivided cities: The potential of economic revitalisation and housing redifferentiation. Housing Studies, 14(5), 573-584.

Nelson, A. C. et al. (1997). Growth management principles and practices. Chicago-Washington D.C.: American Planning Association.

Newman, P., \& Kenworthy, J. (1989). Gasoline consumption and cities: A comparison of US cities with a global survey. Journal of the American Planning Association, 55(1), 24-37. 
Oncu, A. (1997). The myth of the ideal home travels across cultural borders to Istanbul: Space, culture and power: New identities in globalizing cities. In A. Oncu, \& P. Weyland (Eds.). London: Zed Books.

Perouse, J. F., \& Danış, D. (2005). Zenginliğin mekanda yeni yansımaları: İstanbul'da Güvenlikli Siteler (New reflections of richness on the space: Gated communities in Istanbul). Toplum ve Bilim (Society and Science), 104, 92-123.

Şenyapill, T. (2004). Charting the voyage' of squatter housing in urban spatial "Quadruped". Retrieved from http://www.ejts.org/document142.html

Shen, Q., \& Zhang, F. (2007). Land-use changes in a pro-smart-growth state: Maryland, USA. Environment and Planning A, 39(6), 1457-1477.

State Institute of Statistics (SIS). (2000). 1997 Y'lli genel nüfus tespiti kesin sonuçlarí (Final results of general population census of 1997). Retrieved from http://www.die.gov.tr

State Planning Organization (SPO). (1991). Gecekondu araşttrmasl (Survey for squatter). Ankara: SPO.

Suarez, C. C. A. (2011). Gated communities and city marketing: Recent trends in Guaynabo, Puerto Rico. Cities, 28(5), 444-451.

Tokman, B. (1984). Ankara: Procedures for upgrading and urban management in low income housing in the low income housing. New Jersey: John Wiley and Sons.

Webster, C., Glasze, G., \& Frantz, K. (2002). The global spread of gated communities. Environment and Planning B: Planning and Design, 29, 315-320.

Zuidema, P. A., Sayer, J. A., \& Dijkman, W. (1996). Forest fragmentation and biodiversity: The case for intermediate-sized conservation areas. Environmental Conservation, 23, 290-297. 